\title{
TRAINING PROGRAM FOR DESIGNING WOOD AND RESIN-BASED JEWELLERY IN SATRIA SRENGSENG VOCATIONAL HIGH SCHOOL WEST JAKARTA
}

\author{
Junaidi Salam, Ariani Wardhani, Sopyan Tri Atmaja \\ Universitas Mercu Buana Jakarta, Indonesia
}

\begin{abstract}
Jewellery craft is a business with promising opportunity since nowadays numerous materials might be processed into wonderful jewellery as long as the aspects of aesthetic in the jewellery draw the interest of the potential customers and possess the values of beauty and uniqueness. Therefore, rather than being a part of individual collection, jewellery offers good business potentials. In relation to the statement, simple material design in the form of wood waste in combination with resin starts to be an excellent alternative both in the domestic and in the foreign market. In the same time, many designers and also businessmen start to pay attention to market potentials of the products that have been the combination of the two materials. Based on the consideration toward the simple design yet special skills and high level of creativity, the combination of wood waste and resin should be introduced to the public, especially to the students or the teenagers, so that the spirit of creativity altogether with the business potentials might be a role model of entrepreneurship in the future. For ensuring the achievement of this end, a training program in the form of practical materials for the designing process should be designed altogether with the creativity development and the marketing initiatives with low budget. Thereby, the participants of the training program might design jewellery with high sale value yet low budget. Departing from this elaboration, the researcher would like to implement such training program into the community directly. Through the implementation of such program, it is expected that the given community might develop their marketing potentials and business quality. Furthermore, through the implementation of such program, it is also expected that the young designers within the given community becomes well-trained to design the export-scale products to meet both the domestic market and the foreign market. The researcher believes that by introducing the design skills to the young generation, especially to the students, the business spirit and interest might be developed. Then, the training program of designing wood and resin-based jewellery offer good aspects in directing the active business potentials and the positive creativity within the community. One of the efforts that might be pursued in achieving this objective is introducing the design of such jewellery altogether with the practice of jewellery design in the senior and vocational high schools located throughout West Jakarta. Within this initiative, the focus of the study, as part of Community Service Program, is one of the vocational high schools in West Jakarta namely Satria Jakarta Vocational High Schools located in Srengseng 26A RT 5/RW 6, Srengseng, Kembangan, West Jakarta.
\end{abstract}

Keyword : Workshop, Material, Jewellery, Design

\section{INTRODUCTION}

Jewellery might be considered as a business that demands huge fund and effective marketing strategy. In addition to huge fund and effective marketing strategy, an individual will also need knowledge, high sense of courage and creativity in designing the jewelry. The reason is that the jewellery materials are various namely silver, gold, diamond and even other materials that possess the aspects of beauty and from these materials various products might be created such as bracelet, necklace, rings and earrings.

In the path several years, as an alternative, the combination of wood and resin has been turned into the design of jewellery products. Such design has been widely spread to the foreign countries. In the same time, the local industries start to improving the production scale of the jewellery in order to meet the needs of the jewellery market since these industries have been exploring the design of the wood and resin-based jewellery in order to define new creations. Unfortunately, this phenomenon has not been benefitted by the young generation and this is the reason why the researcher would like to uncover the potentials of creativeness among the young people so that they might be inspired to benefit the business opportunities offered by the wood and resin-based jewellery.

The combination between the wood and the resin is made by moulding the patterned wood and pouring the resin into the wooden mould until the resin merges into the wood. When the two elements have been merged, the subsequent process is shaping the wood and resin-combination into jewellery. Although the process might be 
simple, the process demands creativity and special skills in order that the final results of the product might display aesthetic values.

Departing from the above elaboration, practically through the study the researcher would like introduce the process of creating wood and resin-based jewellery by means of research and development initiative to the students of Satria Vocational High School in Srengseng, West Jakarta. Furthermore, through the conduct of the study the researcher would like to expect that the introduction of processing wood and resin-based jewellery might be a discipline in the domain of Design with direct impact toward the community as part of Community Service Program.

\section{LITERATURE REVIEW}

Jewellery aesthetics is the point of sale for the independent businessmen. In this case, jewellery aesthetics might be categorized as the product attribute. Dewi \& Darmawan (Dewi, 2005: 130) state that product refers to a set of attributes and benefits that have been might be considered either less important or more important for the users. Then, according to Peter \& Olson (2005: 546), product attributes are the characteristics of the product, which might be tangible and subjective characteristics such as the quality of a blanket or the stylishness of a car or which might be tangible and physical characteristics of a product such as the type of fibre in a blanket or the front groom in a car.

For marketing business, product attributes might be one of the ways for gaining the upper hand in the market competition. The reason is that the product attributes are the tools that will differentiate the company from its competitors. With regards to the statement, product attributes consist of two kinds namely:

1. Tangible Attribute

Tangible attribute refers to the concrete attributes of the product and might include price, package, quality, design, label and colour.

2. Intangible Attribute

Intangible attribute refers to the abstract attributes of the product and might include reputation and population of the designing company.

In relation to theory and looking at the conditions that have been found in the field, in order to develop the creativity in the domain of jewellery craft there should be a fundamental design creativity and marketing strategy training program so that the possibility of designing the wood and resin-based jewellery might be optimized. Therefore, within the conduct of the study the researcher and also the team of Community Service will review the design and the material selection of wood and resin-based jewellery.

\section{METHOD}

In the study, the method referred to the implementation of the Community Service Program in the form of material selection and design. Then, the method within the conduct of the study consisted of three parts as follows:

1. Survey

In November 2018, both the researcher and the team of Community Service surveyed the research site in order to learn the condition and the situation in the partnering vocational high school, to define the schedule, to identify the educational motto, to identify the students and to analyse the room of practice. Then, moving to the end of the month the researcher and the team of Community Service discussed the survey results and also arranged the training program materials and presentation in accordance to the participants and the conditions in the training ground.

2. Practice

Practice had been selected as the second method so that the training program participants might directly apply the knowledge that they learned. As a way to help the participants to internalize their knowledge, the training instructors also displayed several examples that had been designed.

3. Module

The inclusion of module in the training program was intended to serve as reference materials for the training participants might learn directly the material processing activities. Then, the module that had been implemented was the summary from the writing materials that the instructors considered necessary to include. 
Table 1. Training Method and Activities

\begin{tabular}{|c|c|c|}
\hline STAGES & ACTIVITIES & METHOD \\
\hline \multirow[t]{2}{*}{ Preparation } & $\begin{array}{l}\text { Establishing coordination with the } \\
\text { training participants }\end{array}$ & $\begin{array}{l}\text { Explanation on the intention and the objective of } \\
\text { the training program }\end{array}$ \\
\hline & Designing training materials & Library study and team coordination \\
\hline \multirow[b]{2}{*}{ Training } & $\begin{array}{l}\text { Delivering the theoretical foundation } \\
\text { about the design of jewelers products }\end{array}$ & $\begin{array}{l}\text { Lecture: lecture is selected in providing the } \\
\text { directions on the materials related to the trend in } \\
\text { the jewelers business. } \\
\text { Question and Answer: question and answer is } \\
\text { selected in providing opportunities for the } \\
\text { training participants to understand the training } \\
\text { materials }\end{array}$ \\
\hline & $\begin{array}{l}\text { Introducing the materials and the tools } \\
\text { that might be implemented in processing } \\
\text { the wood and resin-based jewelry }\end{array}$ & $\begin{array}{l}\text { The demonstration is performed by modelling } \\
\text { the stages that should be performed within the } \\
\text { introduction and the selection of the jewelers } \\
\text { product. } \\
\text { The direct practice is performed by providing } \\
\text { direct opportunities to the training participants } \\
\text { to apply directly the stages that they have } \\
\text { learned. }\end{array}$ \\
\hline Evaluation & $\begin{array}{l}\text { Practicing the overall production } \\
\text { process from the beginning until the end } \\
\text { by relying onto the training participants' } \\
\text { own creation }\end{array}$ & $\begin{array}{l}\text { Jewelers Exhibition: through jewelers exhibition } \\
\text { the training participants might display their } \\
\text { work to the surrounding environment so that the } \\
\text { students who have not joined the training } \\
\text { program might be interested. }\end{array}$ \\
\hline
\end{tabular}

\section{ACTIVITY REPORT}

The activities of the training program took place on January $19^{\text {th }}, 2019$, from 11:00 until 17:00 Western Indonesian Time. The training program of jewellery craft was led by the training team and a lecturer named Junaidi Salam, S.Ds., M.Ds. with his students.

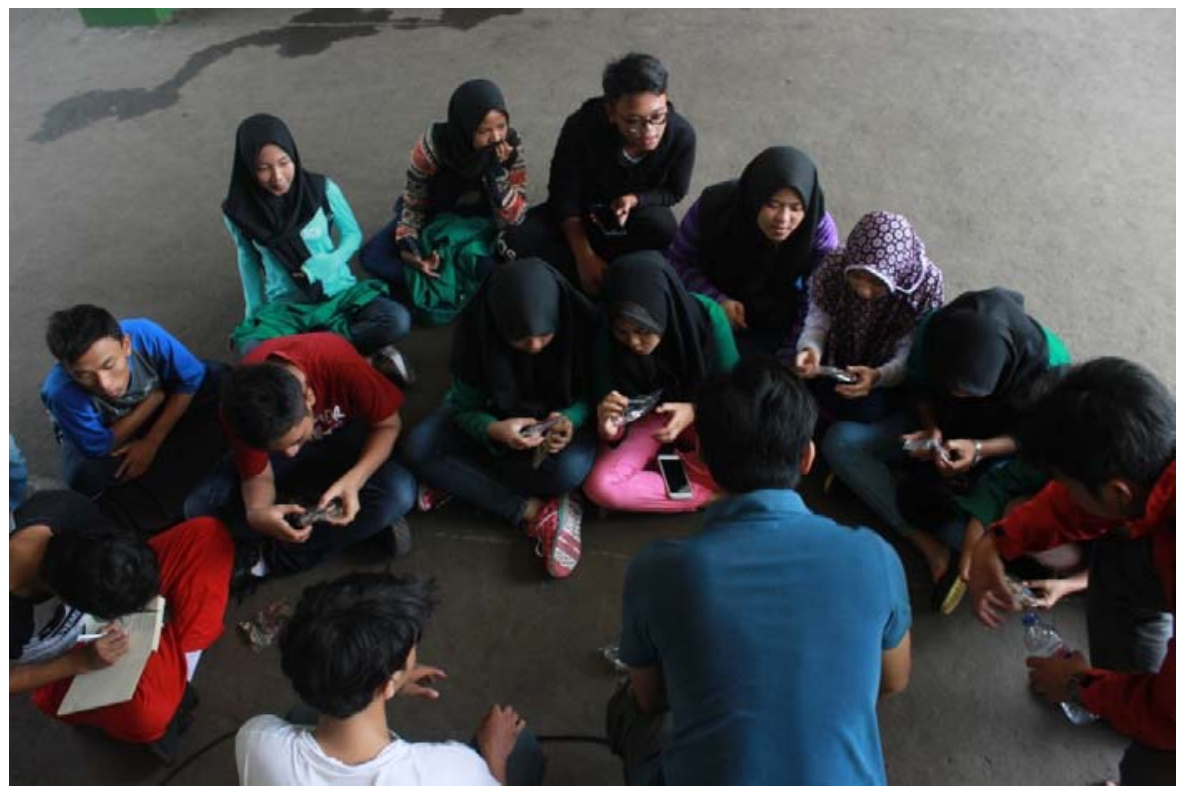

Figure 1. The opening session of wood and resin-based jewellery craft with the students of Satria Vocational High School Srengseng West Jakarta

Source: Salam, 2019

Then, the activities of the training program were divided into two sessions as follows:

1. Session 1

Session 1 consisted of material presentation and wood and resin-based material processing activities from 11:00 until 14:00 Western Indonesian Time by the team of the lecturer Junaidi Salam, S.Ds., M.Ds. 
2. Session 2

Session 2 consisted of material presentation wood and resin-based exploration demo from 14:00 until 17:00 by the team of the lecturer Junaidi Salam, S.Ds., M.Ds.

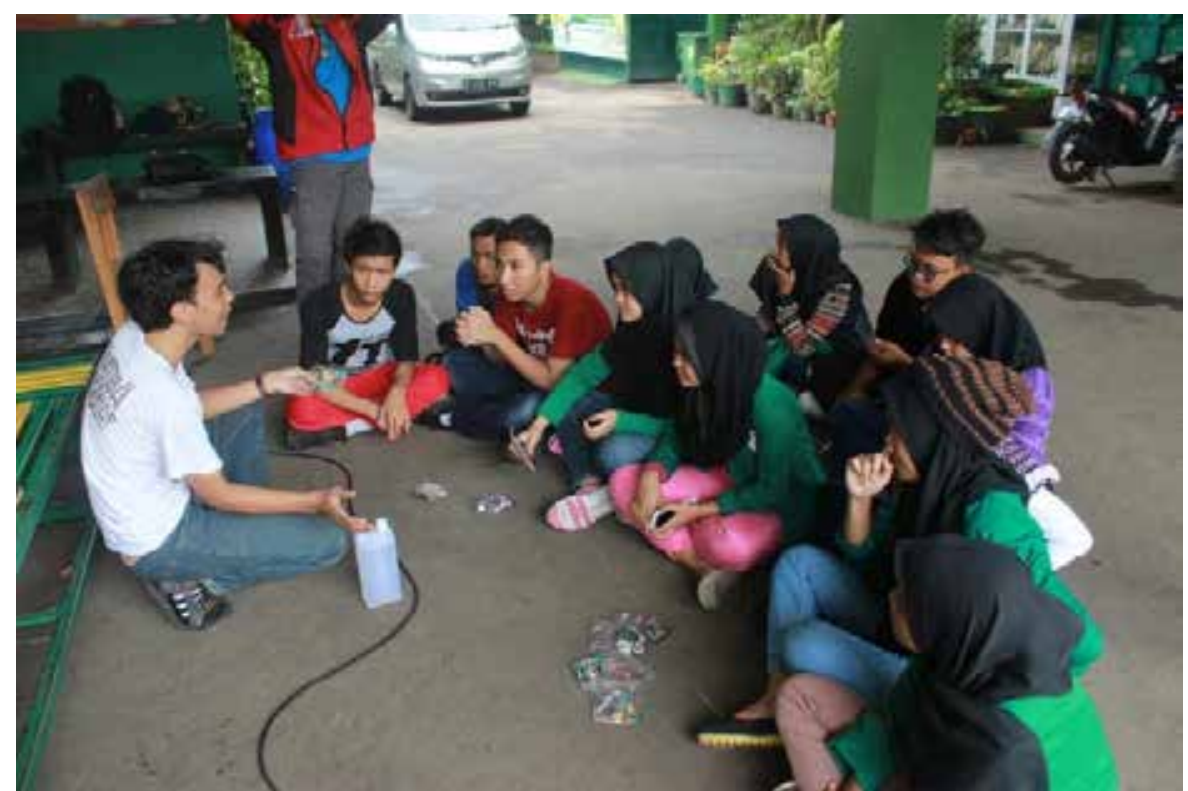

Figure 2. Session 1 activities: material presentation about the jewellery craft by the team members of Community Service in front of the students of Satria Vocational High School Srengseng West Jakarta

Source: Salam, 2019

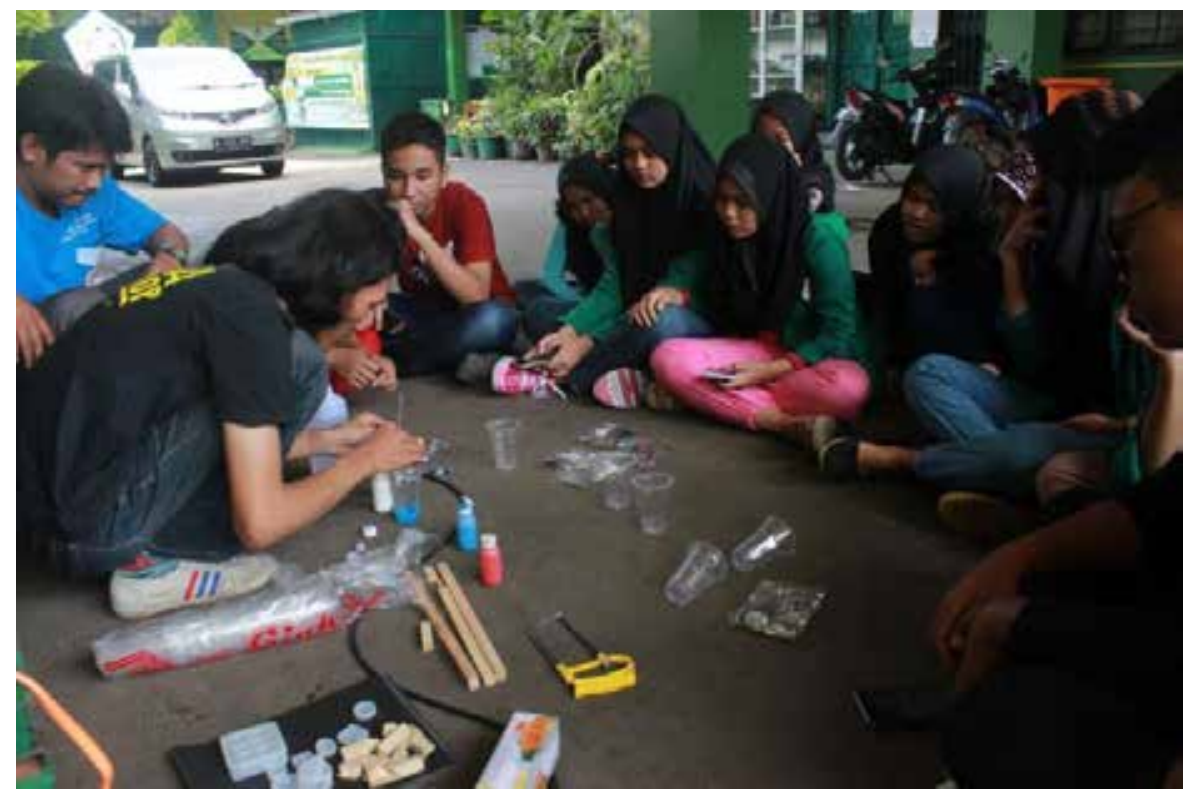

Figure 3. Session 1 activities: material presentation about the jewellery craft by the team members of Community Service in front of the students of Satria Vocational High School Srengseng West Jakarta

Source: Salam, 2019

\section{ANALYSIS}

The training participants range between 15 and 17 years old and all of them display great spirit of entrepreneurship in the early age. Their skills and knowledge might certainly be sufficient equipment in developing the youth creativity through the training programs of designing wood and resin-based jewellery craft. Practically, through the conduct of the study it is expected that the research and development initiative on the 
design of wood and resin-based jewellery craft that involves the students of Satria Vocational High School Srengseng West Jakarta might be an applied discipline in the domain of Design so that the impact of the training program might be directly perceived by the community.

\section{CONCEPT}

Based on the consideration that has been elaborated in the Analysis, the team has decided to select the broken-fibre technique as the concept of the jewellery craft design. After the broken-fibre technique has been implemented, the broken fibre will be wrapped by the resin liquid so that the wood fibre might be bound. Afterward, the wood fibre that has been wrapped by the resin should be dried until the resin becomes hardened and binds the pores of the wood.

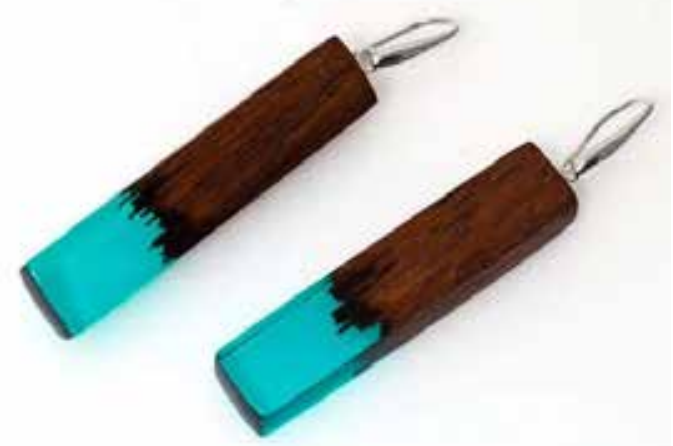

Figure 4. The reference of the jewellery concept that will be provided to the training participants Source: Artfullresin.com

raining Activities

The training activities might be consulted in the following figures.

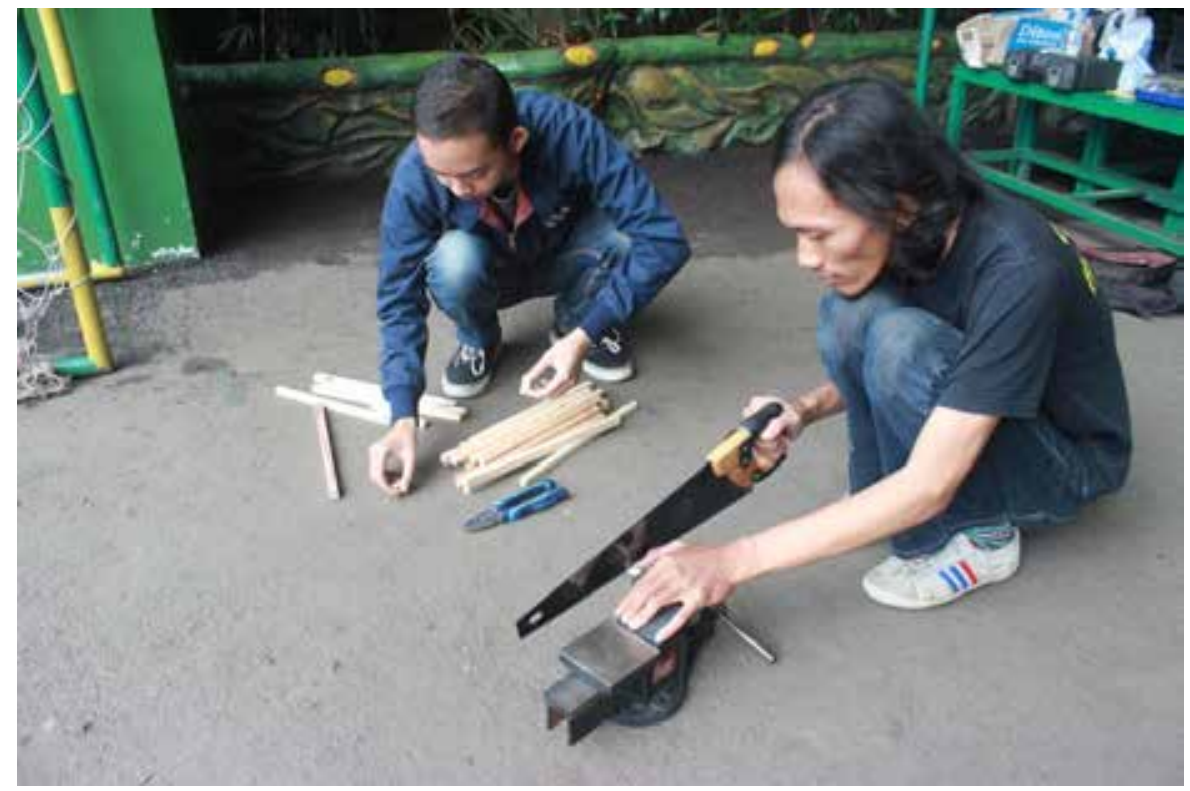

Figure 5. The process of cutting wood by using vice and saw Source: Salam, 2019 


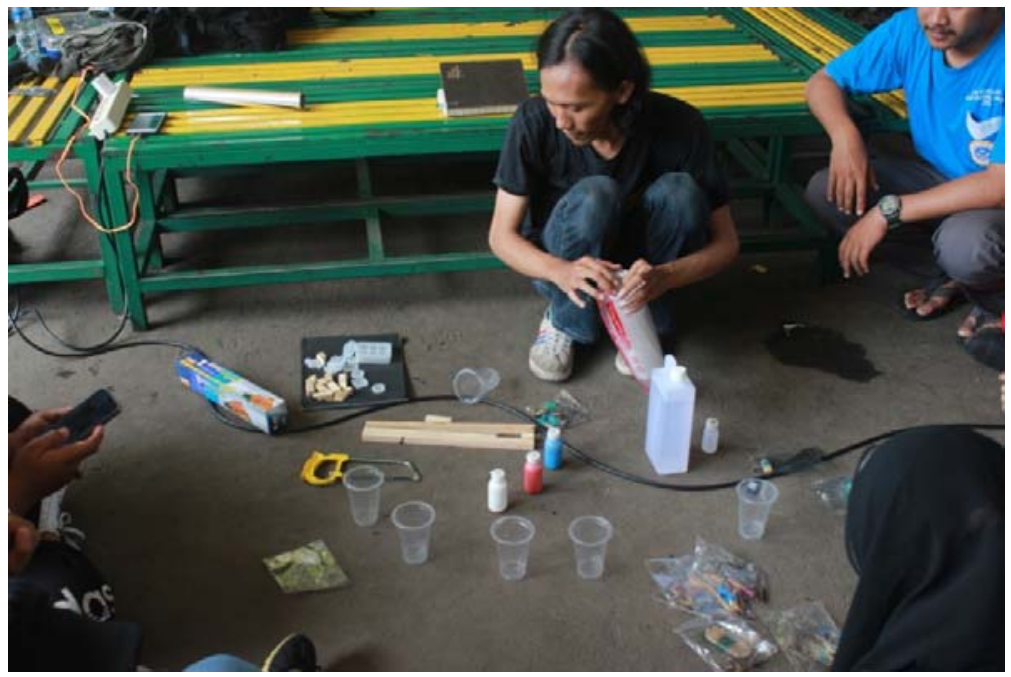

Figure 6. The process of mixing the resin into the catalyst Source: Salam, 2019

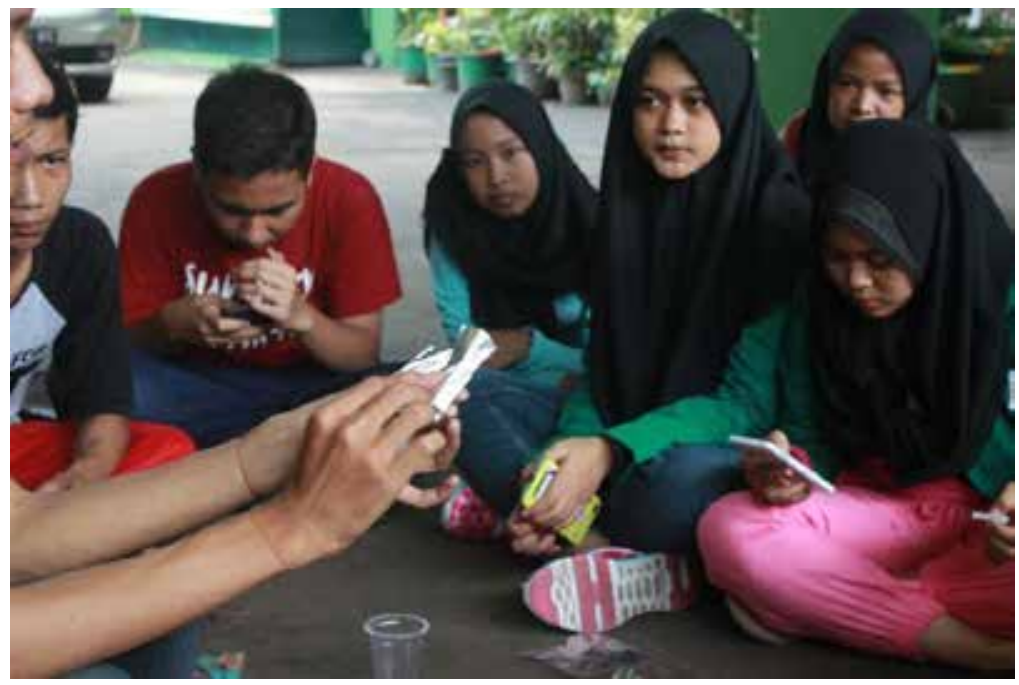

Figure 7. The process of wrapping foil into the wooden materials for serving as the resin mould Source: Salam, 2019

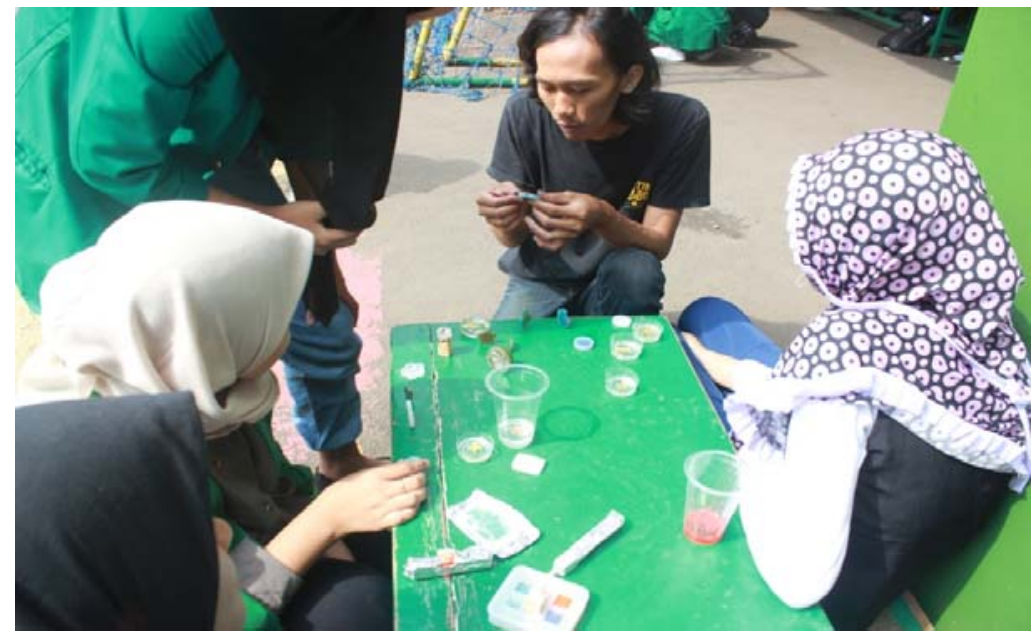

Figure 8. The process of drying wood and resin for the next processing stage Source: Salam, 2019 


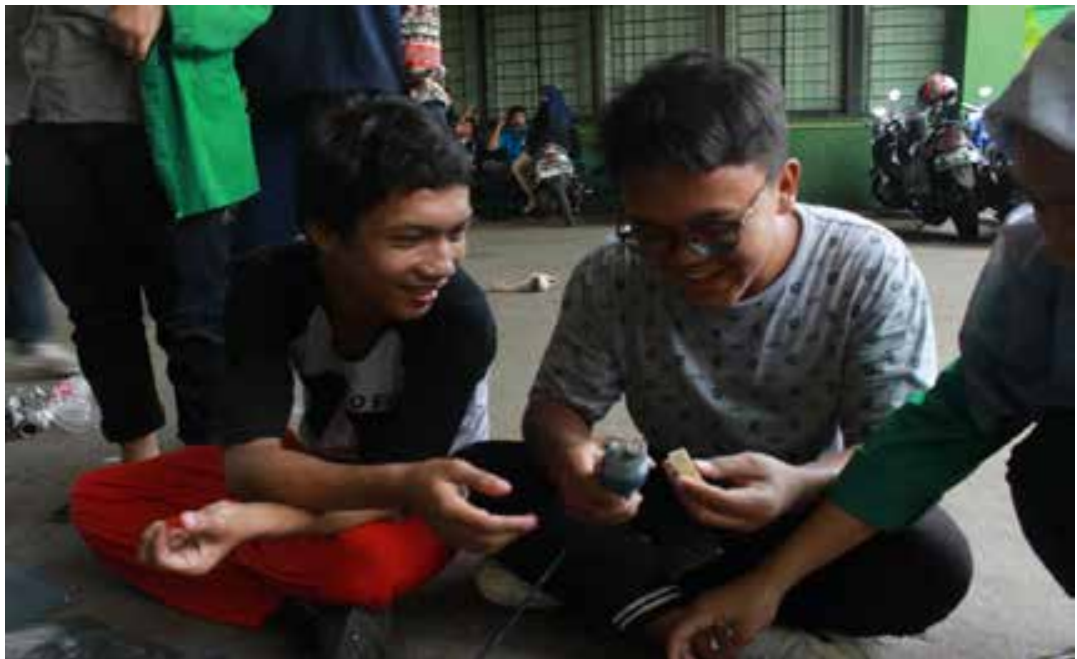

Figure 9. The process of moulding wood and resin that has been mixed Source: Salam, 2019

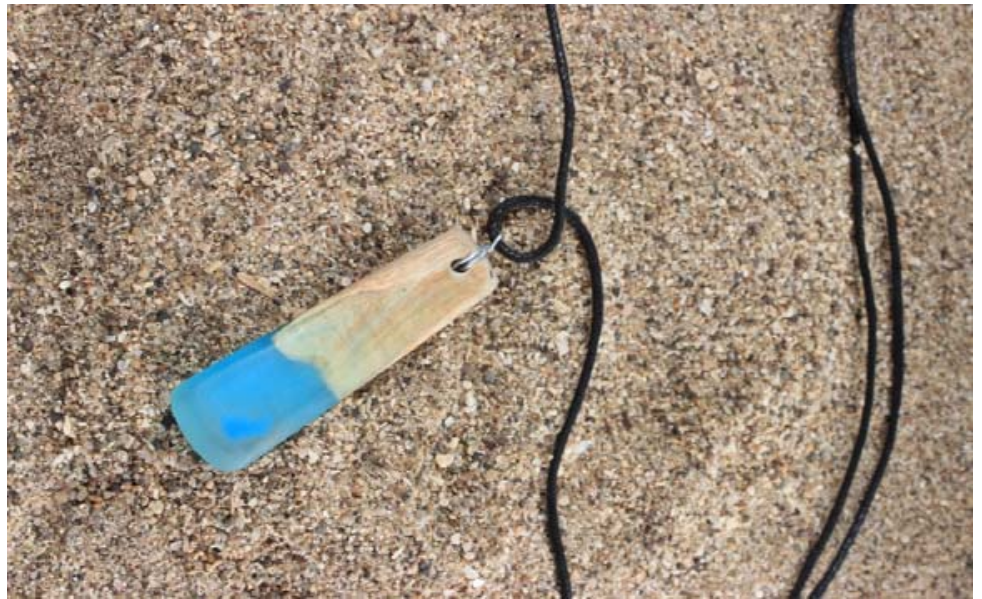

Figure 10. The example of wood and resin-based jewellery craft Source: Salam, 2019

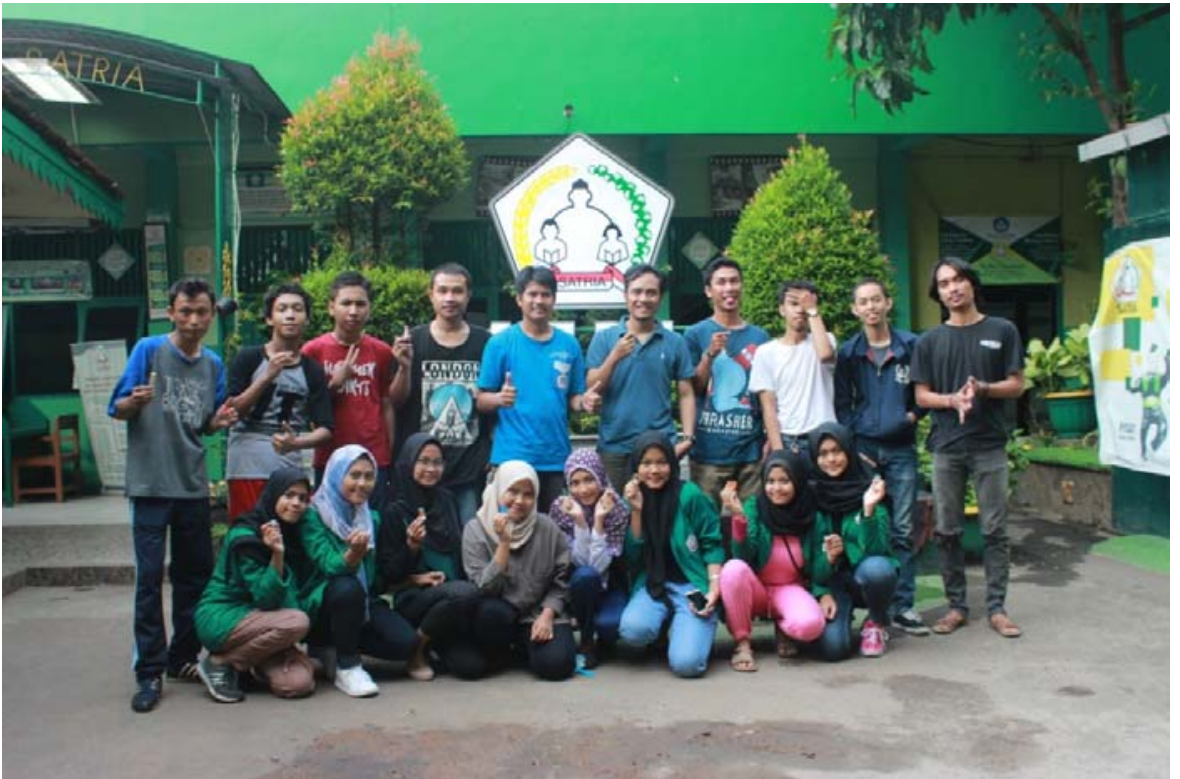

Figure 11. The teachers and the students of Satria Vocational High School Srengseng West Jakarta Source: Salam, 2019 


\section{CONCLUSIONS}

The training program of wood and resin-based jewellery design that has been initiated by the researcher and the team of Community Service has brought good benefits for the participants. First of all, the training program has been able to assist the training participants to understand the characteristics of basic jewellery materials and design tool better, to understand the form of exploration on the wood and resin materials and also the technique of jewellery application. In addition, through the conduct of the training programs the training participants might be assisted to develop their expertise so that their expertise will be beneficial for the entrepreneurship initiative in the future.

On the contrary, for the researcher and the team of Community Service the benefits that might be gained by conducting the training program of wood and resin-based jewellery craft are as follows:

1. Both the researcher and the team of Community Service might apply their knowledge into the community welfare.

2. Both the researcher and the team of Community Service might identify the actual problems within the community and update their knowledge altogether in the same time.

\section{LIST OF REFERENCES}

35 Great Outdoor Projects WOOD MAGAZINE, Sterling Publishing Co, Inc. Park Avenue South, New York, NY 100162005

Hanizzam Awang, MdAzree Othuman Mydinax, 2016. "Contuction Methods and Technology", Universiti Sains Malaysia (Universiti Sains Malaysia Press), 1800 USM Pulau Pinang, Malaysia

Phill Fenton, 2009 "Create your own Sign Making Business from Scratch", New star Publishing, UK. 2009

Rondhi, M dan Sumartono, A.(2002). Tinjauan Seni Rupa I: Hand Out Jurusan Seni Rupa, FBS UNNES Semarang: Semarang

Sanyoto, E, S.(2005). Dasar-Dasar Tata Rupa dan Desain. Arti Bumi Intaran:Yogyakarta.

Sign Guidlines : for planing, designing, fabricating, procuring, instaling, and maintaining sign for outdoor public use areas. U.S Departement of the interior, Bureau of Reclamation, 2006 publicland

Sumanto. (2006). Pengembangan Kreativitas Senirupa Anak SD. Departemen Pendidikan Nasional, Direktorat Jenderal Pendidikan Tinggi, Direktorat Ketenagaan Perguruan Tinggi: Jakarta 